\title{
Fabrication and Characterization of Chitosan/N-Phthaloyl Composite Membrane for DMFC Application
}

\author{
Christine Dyta Nugraeni ${ }^{1}$, Lukman Atmaja ${ }^{2 *}$, Nur Hayati ${ }^{3}$, Mochammad Purwanto ${ }^{4}$, Mardi Santoso ${ }^{2}$, \\ Yuli Kusumawati ${ }^{2}$ \\ ${ }^{1}$ Department of Technology of Fishery Product, Faculty of Fishery and Marine Science, Universitas \\ Borneo Tarakan, North Kalimantan, Indonesia \\ 2Department of Chemistry, Faculty of Science, Institut Teknologi Sepuluh Nopember, East Java, \\ Indonesia \\ ${ }^{3}$ Department of Chemistry, Faculty of Mathematics and Science, Universitas Negeri Surabaya, East Java, \\ Indonesia \\ ${ }^{4}$ Departement of Chemical Engineering, Institut Teknologi Kalimantan, East Kalimantan, Indonesia
}

Corresponding Author: Lukman Atmaja

lukman_at@chem.its.ac.id

Received: February 2021 Accepted: August 2021 Published: September 2021

CLukman Atmaja et al. This is an open-access article distributed under the terms of the Creative Commons Attribution License, which permits unrestricted use, distribution, and reproduction in any medium, provided the original author and source are credited.

\begin{abstract}
Modified chitosan membrane is one of the promising membranes for polymer electrolyte membrane. Chitosan/ $\mathrm{N}$-phthaloyl chitosan composite membranes were fabricated to obtain high proton conductivity and low methanol permeability. Membranes were fabricated by casting method and solvent evaporation. Surface morphology, mechanical analysis, methanol permeability, and proton conductivity were used to characterize the overall properties. FT-IR spectra exhibited the presence of interaction of chitosan and n-phthaloyl/chitosan. SEM analysis showed that the surface roughness of composite membrane increases as the $\mathrm{n}$-phthaloyl loading increases. The highest proton conductivity of synthesized membrane is at $2.4 \mathrm{mS} . \mathrm{cm}-1$ and is higher than pristine chitosan membrane at $1.6 \mathrm{mS} . \mathrm{cm}-1$. Moreover, with nphthaloyl/chitosan addition, the methanol permeability was also improved. The correlation between proton conductivity and methanol permeability in composite membranes suggests that the blend has its potential in DMFC application.
\end{abstract}

Keywords: chitosan, membrane, proton exchange, N-phthaloyl chitosan

\section{Introduction}

Direct Methanol Fuel Cell (DMFC) is projected to become the important fuel cell due to high energy density, renewable fuel source, easy transport, and simple refuel ${ }^{[1]-[4]}$. In a DMFC system, the proton exchange membrane represents a main major component that delivers proton from anode to cathode as well as to block methanol permeation[1],[5]. The characteristics of good proton exchange membranes are high proton conductivity, low methanol permeability, great performance for

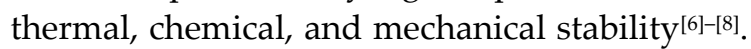
Nafion ${ }^{\circledR}$, a perfluorosulfonic acid polymer membrane, is considered the most preferred 
DMFC proton exchange membrane for years $\left[{ }^{[0,[10]}\right.$ having most of the desired properties such as favorable proton conductivity, superior thermal, chemical, and mechanical stability ${ }^{[10]-}$ [12]. Nevertheless, some drawbacks also existed like expensive material, high methanol permeability, reduced efficiency at low humidity, and high temperature[13],[14]. The disadvantages of Nafion ${ }^{\circledR}$ membrane have inspired the development of alternative membrane material integrated with low cost, high proton conductivity, and low methanol permeability[15],[16].

The use of natural polymer composite membrane has been investigated extensively to be applied as proton exchange membrane in fuel cells as it has advantageous properties such as biodegradable, biocompatible, renewable, sustainable, and low cost source ${ }^{[17],[18]}$. Chitosan is one of the natural polymer materials derived from chitin which has found a wide range of crustacean waste ${ }^{[19]}$. Membrane from this abundantly available material has low methanol permeability and cationic polyelectrolyte due to the presence of hydroxyl and amine groups ${ }^{[20]}$. However, the very low proton conductivity limits its application on a reasonable scale. Chemical, a structural modification could be used to enhance the properties of chitosan membrane[17].

The utilization of glycol chitosan as bases on the membrane has been investigated. The modified chitosan was reported to have improved solubility, compatibility, and hydrophobic, hydrophilic properties ${ }^{[21]}$. The use of crosslinking agents like sulfuric acid has also been studied. Chitosan membrane has lower performance than Nafion ${ }^{\circledR}$ membrane mainly due to its hydrophobicity and an improvement will enhance the ionic conductivity ${ }^{[22]}$. A potential way to raise the hydrophobicity is by $\mathrm{N}$ phthaloylation process using phthalic anhydride addition. The introduction of $\mathrm{N}$ phthaloyl to the sulfonated polyethersulfone was reported to improve proton conductivity and reduce methanol permeability ${ }^{[17]}$.

In our research, $\mathrm{N}$-phthaloyl/chitosan composite and pristine chitosan on a unique composition were prepared as the material of the membrane. Chitosan N-phthaloyl could promote proton transportation due to the contribution of a carboxyl group. We investigated membrane preparation, fabrication procedures, and membrane properties for direct methanol fuel cell application.

\section{Experimental}

\section{Materials}

The chitosan powder was synthesized from shrimp shell waste of Litopenaeus vannamei. The following reagents were obtained from Merck, methanol, acetic acid anhydride, ethanol, N, N dimethylformamide (DMF), cyclohexane, sodium hydroxide pellet, and phthalic anhydride. Hydrochloric acid and sulfuric acid were purchased from local industries.

\section{Methods}

\section{Chitosan extraction}

Chitosan was produced in three steps ${ }^{[23]}$. Firstly, deproteination step, shrimp shell powder was dissolved with stirring in $3.5 \% \mathrm{NaOH}$ solution at $65{ }^{\circ} \mathrm{C}$ for $2 \mathrm{~h}$. The sample was washed with distilled water until neutral $\mathrm{pH}$ and later dried. Secondly, de-mineralization step, the dried powder was treated by stirring in $1 \mathrm{M} \mathrm{HCl}$ solution at $65^{\circ} \mathrm{C}$ for 30 minutes. The sample was washed in distillate water until a neutral $\mathrm{pH}$ was reached and then dried. This reaction was formed chitin. Finally, de-acetylation to remove the acetyl group from chitin. $50 \% \mathrm{NaOH}$ was added to chitin with stirring at $120^{\circ} \mathrm{C}$ for $4 \mathrm{~h}$. The product was rinsed until neutral $\mathrm{pH}$ and dried. The product was grinded to obtain chitosan powder.

\section{Synthesis of N-phthaloyl/chitosan}

Chitosan (10 g) and phthalic anhydride (27.6 g) were refluxed for $6 \mathrm{~h}$ and $130{ }^{\circ} \mathrm{C}$ using dimethylformamide (DMF) solution in a nitrogen environment. The solution was precipitated into water ice and later purified with ethanol and diethyl ether. The Nphthaloyl/chitosan synthesized was subsequently heated until dried out at $60^{\circ} \mathrm{C}$. 


\section{Preparation of membrane}

PCh-Ch composite membranes were fabricated by evaporation technique. chitosan ( $2 \mathrm{~g})$ was diluted in $80 \mathrm{~mL}$ acetic acid solution $2 \%$ with stirring for 30 minutes. In different parts, $10 \mathrm{~mL}$ of dimethylformamide was used to dissolve $\mathrm{N}$ phthaloyl/chitosan at various compositions (25 and $50 \mathrm{mg} / \mathrm{g}$ of chitosan weight). Both compounds were blended and agitated for 15 minutes at room temperature. The blended solution was homogenized by a sonicator for 30 minutes. The solution was prepared in the casting method and dried for 3 days at $60{ }^{\circ} \mathrm{C}$ to obtain the composite membrane. The composite membrane that consists of $\mathrm{N}$ phthaloyl/chitosan at 25 and $50 \mathrm{mg} / \mathrm{g}$ of chitosan weight is symbolized with PCh25/Ch and PCh50/Ch, respectively.

\section{Structural characterization (FTIR)}

The membranes were mixed with $\mathrm{KBr}$ and formed to pellet at room temperature. The spectra were evaluated in the wavenumber range of 4000-800 $\mathrm{cm}^{-1}$ using Shimadzu 8400 .

\section{Scanning electron microscope studies}

Zeiss Evo Ma10 scanning electron microscope was used to record SEM images of the fabricated composite membrane surfaces. The analysis was carried out under magnification ranging from 2000x to $3000 x$.

\section{Mechanical properties of membranes}

Tensile tests of the synthesized blend membranes were carried out using Strograph VG10-E at elongation velocity of $100 \mathrm{~mm} . \mathrm{min}^{-1}$ at room temperature.

\section{Methanol crossover}

The methanol crossover measurement was performed by diffusion experiments. The diffusion cell was divided into two chambers was separated membrane. One chamber was filled with $5 \mathrm{M}$ methanol solution and the other chamber was filled with deionized water. The both of chamber was kept stirring during the experiment. The concentration of methanol in the deionized water chamber was examined every 20 minutes using a pycnometer. The methanol crossover values were obtained by following equation (1).

$C_{B}(t)=\frac{S}{V_{B}} \frac{P}{L} C_{A}\left(t-t_{0}\right)$

where $\mathrm{V}_{\mathrm{B}}$ is the volume of deionized water, $\mathrm{L}$ is membrane thickness, $C_{A}$ represents the methanol concentration in the deionized water chamber, С $C_{B}$ represents the methanol concentration and $\mathrm{P}$ is the methanol crossover calculated from concentration change-time line slope.

\section{Proton conductivity}

The proton conductivity of synthesized membranes was characterized by the AC impedance technique at room temperature. The membrane conductivity values were calculated as:

$\sigma=\frac{\mathrm{L}}{\mathrm{R} \times \mathrm{A}}$

where $\sigma$ is the conductivity, A surface area of the sample, $\mathrm{R}$ resistance, and $\mathrm{L}$ sample thickness.

\section{Results and Disscusion}

FTIR spectroscopy was used to examine chitosan powder, $\mathrm{N}$ phthaloyl/chitosan powder, and composite membranes are shown in Figure 1 . The chitosan can identify by peaks to related $\mathrm{O}-\mathrm{H}$ stretching at $3433 \mathrm{~cm}^{-1}, \mathrm{C} \mathrm{H}$ stretching at $2887 \mathrm{~cm}^{-1}, \mathrm{C} \mathrm{H}$ stretching at $1653 \mathrm{~cm}^{-1}, \mathrm{C}=\mathrm{O}$ stretching at $1595 \mathrm{~cm}^{-1}, \mathrm{~N}-\mathrm{H}$ stretching at 1381 $\mathrm{cm}^{-1}$, and C-N at stretching $1151 \mathrm{~cm}^{-1}$. This is supported by analyzed FT-IR spectra of chitosan observed by Fernandes Queiroz [24]. Figure 1(a) shows the FTIR spectrum of Nphthaloyl/chitosan. Signal of imide $\mathrm{C}=\mathrm{O}$ stretching vibrations (1774 and $1710 \mathrm{~cm}^{-1}$ ) could be detected in N-phthaloyl/chitosan spectrum. This is explained by fact that $\mathrm{N}$ phthaloyl/chitosan was formed[17]. The IR spectra for synthesized membrane with various 
content of $\mathrm{N}$ phthaloyl/chitosan are shown in Figure $1(\mathrm{c})$ and $(\mathrm{d})$. The considerable decrease in intensity of the O-bridge stretching in the spectrum of $\mathrm{N}$-phthaloyl/chitosan membrane indicates that the greater amount of $\mathrm{N}$ phthaloyl/chitosan affects the crosslinking chains in membranes.

Figure 2 shows SEM photographs of chitosanN-phthaloyl/chitosan composite membrane with $\mathrm{N}$ phthaloyl/chitosan content fabricated during this study. The composite membrane exhibited a homogeneous structure and rough surface in morphology. The homogenous structure without interphase separation indicated good phase compatibility between chitosan and N-phthaloyl/chitosan. The uniform distribution has advantages like supplying a proton conductivity pathway ${ }^{[25]}$. The higher amount of N-phthaloyl/chitosan was produced a rougher surface due to lower crosslinking available in the membrane. The crosslinking in the proton exchange can lead to decrease methanol permeability due to cover porous and improve the dense of the membrane ${ }^{[26]}$.

The mechanical property of the proton exchange membrane is important in DMFC[27]. The Young modulus, yield stress, and maximum elongation of the blended membrane are showed in Table 1. Compared to the membrane of chitosan pristine, membranes with N-Phthaloyl/chitosan have better mechanical properties. It can be seen that yield stress and elongation of composite membrane elevated with $\mathrm{N}$ phthaloyl/chitosan loading. At higher N Phthaloyl/chitosan content the blended membrane show improvement in Young modulus and the formation of a better network leads to higher stress.

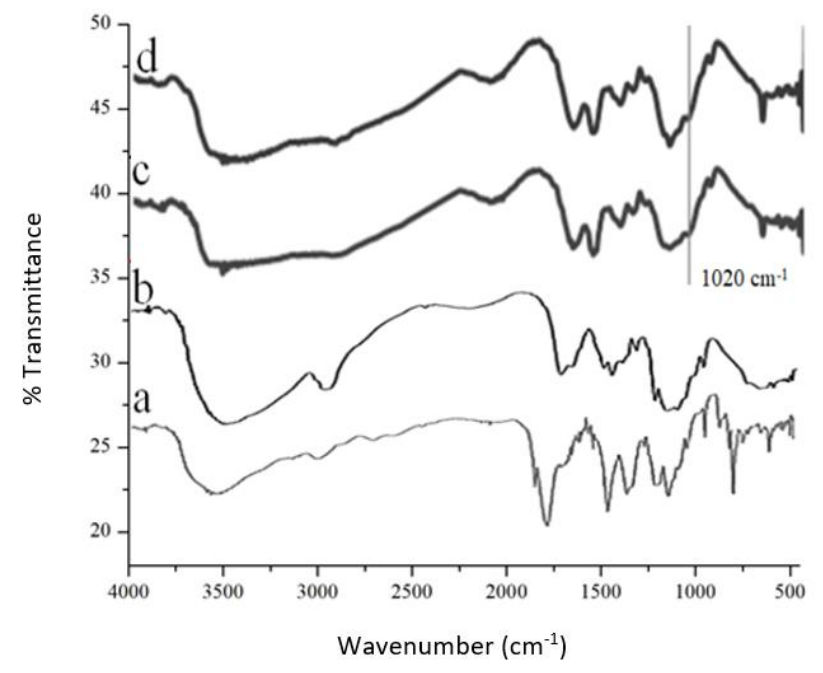

Figure 1. FTIR Spectra for a) N-phthaloyl/chitosan, b) Chitosan, c) PCh25/Ch, d) PCh50/Ch.

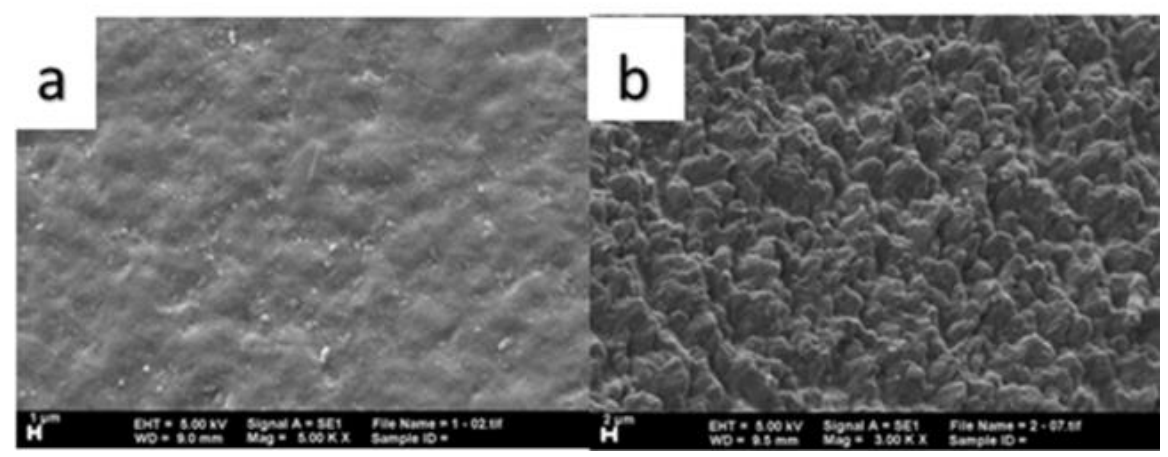

Figure 2. SEM images for a) PCh25/Ch, b) PCh50/Ch. 
Tabel 1. Mechanical properties of membrane

\begin{tabular}{ccccc}
\hline Sample & $\begin{array}{c}\text { Young } \\
\text { Modulus } \\
\mathbf{( M P a )}\end{array}$ & $\begin{array}{c}\text { Yield } \\
\text { Stress } \\
\mathbf{( M P a )}\end{array}$ & $\begin{array}{c}\text { Max. } \\
\text { Elongation } \\
\mathbf{( \% )}\end{array}$ & Reference \\
\hline PCh25/Ch & 96.6 & 11.1 & 8.4 & \\
PCh50/Ch & 146.0 & 10.5 & 5.7 & [28] \\
Chitosan & - & 6.05 & 1.5 & [29] \\
Nafion 115 & 93.7 & 19.4 & 92.2 & \\
\hline
\end{tabular}

An increase in Young modulus is caused by the excess bond between chitosan and $\mathrm{N}$ phthaloyl/chitosan in the membrane. The reduction in yield stress and elongation are attributed to limited chain motion due to the existence of the Chitosan - N-Phthaloyl/Chitosan complex which decreases the chain flexibility and crosslink amount between chitosan molecules. The composite membrane with the highest content of $\mathrm{N}$ phthaloyl/chitosan has a higher Young modulus but lower yield stress and elongation than that of the composite membrane with lower content. The yield stress and break elongation of the synthesized membrane are lower than Nafion 115.

The permeability of methanol is an important criterion for DMFC application. Methanol permeability is the capability to restrict methanol as fuel. The drawbacks of high methanol permeability in the DMFC system are leading to poisoning the cathode catalysts and open-circuit potential[30]. The transport of methanol from the anode to the cathode by diffusion in the membrane leads undesired reaction at the cathode catalyst. In this research, the methanol permeability of synthesized membranes was determined. The methanol permeability is shown in Table 2. The greater Chitosan/N-Phthaloyl content shows lower methanol permeability due to forming of hydrophilic channels.

The proton conductivity of the membrane was measured to investigate the contribution of the functional group in the membrane to the formation of an ionic cluster. The proton conductivity values increase with a larger size or/and amount of ionic cluster due to elevated proton transport. The previous research about the addition of Chitosan/N-phthaloyl in SPES (sulfonated polyethersulfone) showed that Chitosan/N-phthaloyl increased the proton conductivity due to the excess the polar group in Chitosan/N-phthaloyl which formed hydrophilic region in the membrane ${ }^{[17]}$.

Tabel 2. Methanol crossover, proton conductivity, and selectivity of composite membrane

\begin{tabular}{|c|c|c|c|c|}
\hline Membranes & $\begin{array}{c}\text { Methanol } \\
\text { Permeability } \\
\left(\mathrm{cm}^{2} \mathrm{~s}^{-1}\right)\end{array}$ & $\begin{array}{c}\text { Proton } \\
\text { Conductivity } \\
\left(\mathrm{mS} \mathrm{cm}^{-1}\right)\end{array}$ & $\begin{array}{l}\text { Selectivity } \\
\left({\left.\mathrm{S} . s ~ \mathrm{~cm}^{-3}\right)}^{-}\right.\end{array}$ & Reference \\
\hline PCh25/Ch & $1.5 \times 10^{-4}$ & 2.4 & 16.2 & \\
\hline PCh50/Ch & $2.3 \times 10^{-4}$ & 0.2 & 1.0 & \\
\hline Chitosan & $3.8 \times 10^{-7}$ & 1.6 & $9.0 \times 10^{3}$ & [6] \\
\hline Nafion 117 & $25.0 \times 10^{-7}$ & 31.6 & $1.26 \times 10^{4}$ & [23] \\
\hline
\end{tabular}


The proton conductivity data for composite membrane with various concentrations of Chitosan/N-Phthaloyl is given in Table 2. The results obtained for PCh25/Ch membrane exhibit higher proton conductivity than chitosan membrane due to the present carbonyl function as proton acceptor and ionic cluster. The presence of excess $\mathrm{N}$ phthaloyl inhibits the proton transport due to the high hydrophobic phthaloyl group in chitosan phthaloyl and low crosslink in the membrane. The high hydrophobic in the membrane can disrupt the mobility of transport due to absorption of water decrease which facilitates proton transport. The crosslink in the membrane can be improved by the formation of a transport channel. The difference of the base membrane component can carry different reactions in methanol permeability. It showed in Chitosan/Nphthaloyl in SPES (sulfonated polyethersulfone) membrane. The addition of Chitosan/Nphthaloyl decreased methanol permeability due to enhanced tortuosity and blockage of membrane pores [17].

The selectivity of the composite membrane was calculated as the ratio of proton conductivity and methanol permeability. The higher selectivity is related to the high performance of the proton exchange membrane in DMFC application ${ }^{[21]}$. Among all composite membranes in this study, PCh25/Ch exhibits the highest proton conductivity as well as highest selectivity. Compared with the selectivity value of chitosan membrane (16.2 S.s cm-3), PCh25/Ch has low selectivity.

\section{Conclusions}

The composite membrane of Chitosan/Nphthaloyl and chitosan for DMFC was prepared and characterized. The composite membrane exhibited good mechanical properties due to a good network of Chitosan and Chitosan/NPhthaloyl. The rough surfaces and high Young modulus increase with the increase of Chitosan/N-Phthaloyl concentration. The highest proton conductivity of membrane fabricated is at $2.4 \mathrm{mS} . \mathrm{cm}^{-1}$ and is higher than pristine chitosan membrane at $1.5 \mathrm{mS} \mathrm{cm}^{-1}$.
$\mathrm{CS} / \mathrm{PhC}(25)$ demonstrated the highest selectivity of all fabricated membranes at $5.627 \mathrm{mS} . \mathrm{cm}^{-1}$. The results indicate that the synthesized membrane needs to modify with inorganic filler or other conductive material for conductivity improvement. The crosslinking agent loading is necessary to increase elongation break and decrease methanol permeability.

\section{Acknowledgments}

This work was support by DIPA Universitas Borneo Tarakan.

\section{References}

1. Uma Devi, A., Divya, K., Rana, D., Sri Abirami Saraswathi, M. \& Nagendran, A., Highly selective and methanol resistant polypyrrole laminated SPVdF-co$\mathrm{HFP} / \mathrm{PW}$ A proton exchange membranes for DMFC applications. Mater. Chem. Phys., 212: 533-542 (2018).

2. Wei, Y., Shen, L., Wang, Z., Yang, W. D., Zhu, H. \& Liu, H., A novel membrane for DMFC-Na2Ti3O7 nanotubes/Nafion ${ }^{\circledR}$ composite membrane. Int. J. Hydrogen Energy, 36(8): 5088-5095 (2011).

3. Solanki, J. N., Mishra, P. S. \& Murthy, Z. V. P., Enhanced performance of DMFC prepared by $10 \mathrm{Cu} / \mathrm{CeO} 2$ catalyst and nanocomposite SPVA membranes with layer-by-layer coating of polyacrylic acid and chitosan. Int. J. Hydrogen Energy, 42(18): 13198-13208 (2017).

4. Shaari, N. \& Kamarudin, S. K., Performance of crosslinked sodium alginate/sulfonated graphene oxide as polymer electrolyte membrane in DMFC application: RSM optimization approach. Int. J. Hydrogen Energy, 43(51): 22986-23003 (2018).

5. Prapainainar, P., Maliwan, S., Sarakham, K., Du, Z., Prapainainar, C., Holmes, S. M. \& Kongkachuichay, P., Homogeneous polymer/filler composite membrane by spraying method for enhanced direct methanol fuel cell performance. Int. J. Hydrogen Energy, 43(31): 14675-14690 (2018). 
6. Wu, Q., Wang, H., Lu, S., Xu, X., Liang, D. \& Xiang, Y., Novel methanol-blocking proton exchange membrane achieved via self-anchoring phosphotungstic acid into chitosan membrane with submicro-pores. J. Memb. Sci., 500: 203-210 (2016).

7. Li, C., Yang, Z., Liu, X., Zhang, Y., Dong, J., Zhang, Q. \& Cheng, H., Enhanced performance of sulfonated poly (ether ether ketone) membranes by blending fully aromatic polyamide for practical application in direct methanol fuel cells (DMFCs). Int. J. Hydrogen Energy, 42(47): 28567-28577 (2017)

8. Divya, K., Sri Abirami Saraswathi, M. S., Alwarappan, S., Nagendran, A. \& Rana, D., Sulfonated poly (ether sulfone)/poly (vinyl alcohol) blend membranes customized with tungsten disulfide nanosheets for DMFC applications. Polymer (Guildf)., 155: 42-49 (2018).

9. Omosebi, A. \& Besser, R. S., Electron beam patterned Nafion membranes for DMFC applications. J. Power Sources, 228: 151-158 (2013).

10. Divya, K., Sri Abirami Saraswathi, M. S., Rana, D., Alwarappan, S. \& Nagendran, A., Custom-made sulfonated poly (ether sulfone) nanocomposite proton exchange membranes using exfoliated molybdenum disulfide nanosheets for DMFC applications. Polymer (Guildf)., 147: 48-55 (2018).

11. Ercelik, M., Ozden, A., Devrim, Y. \& Colpan, C. O., Investigation of Nafion based composite membranes on the performance of DMFCs. Int. J. Hydrogen Energy, 42(4): 2658-2668 (2017).

12. Ranjani, M., Yoo, D. J. \& Gnana kumar, G., Sulfonated Fe3O4@SiO2 nanorods incorporated sPVdF nanocomposite membranes for DMFC applications. J. Memb. Sci., 555: 497-506 (2018).

13. Pasini Cabello, S. D., Mollá, S., Ochoa, N. A., Marchese, J., Giménez, E. \& Compañ, V., New bio-polymeric membranes composed of alginate-carrageenan to be applied as polymer electrolyte membranes for DMFC. J. Power Sources, 265: 345-355 (2014).
14. Hidayati, N., Mujiburohman, M., Abdillah, H., Purnama, H., Dwilaksita, A., Zubaida, F. R. \& Kahfi, A., Chitosan-ABS membrane for DMFC: effect of sulfonation time and mass ratio of chitosan and ABS. in AIP Conference Proceedings, 1977: 030042 AIP Publishing LLC, (2018).

15. Devi, A. U., Divya, K., Kaleekkal, N. J., Rana, D. \& Nagendran, A., Tailored SPVdFco-HFP/SGO nanocomposite proton exchange membranes for direct methanol fuel cells. Polymer (Guildf)., 140: 22-32 (2018).

16. Amoozadeh, A., Mazdarani, H., Beydaghi, H., Tabrizian, E. \& Javanbakht, M., Novel nanocomposite membrane based on Fe3O4@TDI@TiO2-SO3H: hydration, mechanical and DMFC study. New J. Chem., 42(20): 16855-16862 (2018).

17. Muthumeenal, A., Neelakandan, S., Kanagaraj, P. \& Nagendran, A., Synthesis and properties of novel proton exchange membranes based on sulfonated polyethersulfone and N-phthaloyl chitosan blends for DMFC applications. Renew. Energy, 86: 922-929 (2016).

18. Shaari, N. \& Kamarudin, S. K., Chitosan and alginate types of bio-membrane in fuel cell application: An overview. J. Power Sources, 289: 71-80 (2015).

19. Osman, Z. \& Arof, A. K., Chitosan and phthaloylated chitosan in electrochemical devices. in Biological Activities and Application of Marine Polysaccharides, InTech, 303-318 (2017).

20. Permana, D., Purwanto, M., Ramadhan, L. O. A. N. \& Atmaja, L., Synthesis and characterization of chitosan/phosphotungstic acidmontmorillonite modified by silane for DMFC membrane. Indones. J. Chem., 15(3): 218-225 (2015).

21. Horimatsu, N., Takahashi, T., Kobayashi, D., Shono, A. \& Otake, K., Development of polystyrene sulfonate/glycol chitosan hybrid membrane for direct methanol fuel cell. Desalin. Water Treat., 51(25-27): 52545259 (2013). 
22. Osifo, P. O. \& Masala, A., Characterization of direct methanol fuel cell (DMFC) applications with $\mathrm{H} 2 \mathrm{SO} 4$ modified chitosan membrane. J. Power Sources, 195(15): 49154922 (2010).

23. Purwanto, M., Atmaja, L., Mohamed, M. A., Salleh, M. T., Jaafar, J., Ismail, A. F., Santoso, M., et al., Biopolymer-based electrolyte membranes from chitosan incorporated with montmorillonitecrosslinked GPTMS for direct methanol fuel cells. RSC Adv., 6(3): 2314-2322 (2016).

24. Queiroz, M. F., Melo, K. R. T., Sabry, D. A., Sassaki, G. L. \& Rocha, H. A. O., Does the use of chitosan contribute to oxalate kidney stone formation? Mar. Drugs, 13(1): 141-158 (2015).

25. Parthiban, V. \& Sahu, A. K., Performance enhancement of direct methanol fuel cells using a methanol barrier boron nitrideNafion hybrid membrane. New J. Chem., 44(18): 7338-7349 (2020).

26. Berghuis, N. T., Zulfikar, M. A. \& Wahyuningrum, D., Sintesis membran komposit berbahan dasar kitosan dengan metoda sol-gel sebagai membran fuel cell pada suhu tinggi. al-Kimiya J. Ilmu Kim. dan Terap., 7(1): 35-46 (2020).
27. Muliawati, E. C., Santoso, M., Ismail, A. F., Jaafar, J., Salleh, M. T., Nurherdiana, S. D. \& Widiastuti, N., Membran campuran daripada poli(eugenol sulfonat) dan polieterimida sulfonat yang menjanjikan untuk sel bahan api metanol langsung. Malaysian J. Anal. Sci., 21(3): 659-668 (2017).

28. Wang, W., Shan, B., Zhu, L., Xie, C., Liu, C. \& Cui, F., Anatase titania coated CNTs and sodium lignin sulfonate doped chitosan proton exchange membrane for DMFC application. Carbohydr. Polym., 187: 35-42 (2018).

29. Yuan, Z., Duan, Y., Liu, T., Zhang, H. \& Li, $X .$, Toward a low-cost alkaline zinc-iron flow battery with a polybenzimidazole custom membrane for stationary energy storage. iScience, 3: 40-49 (2018).

30. Zhao, C., He, D., Li, Y., Xiang, J., Li, P. \& Sue, H.-J., High-performance proton exchange membranes for direct methanol fuel cells based on a SPEEK/polybenzoxazine crosslinked structure. RSC Adv., 5(59): 47284-47293 (2015). 